\title{
SFAS 141(R): Global Convergence And Massive Changes In M\&A Accounting
}

\author{
Christine Andrews, Florida Gulf Coast University, USA \\ Jan Falmer, Gartner, Inc., Fort Myers, Florida, USA \\ Jeannette Riley, Crossroads Baptist Church, Fort Myers, Florida, USA \\ Carrie Todd, Gartner, Inc., Fort Myers, Florida, USA \\ Ara Volkan, Florida Gulf Coast University, USA
}

\begin{abstract}
The Financial Accounting Standards Board issued SFAS 141(R) in December 2007 to replace SFAS 141. Analyzing comment letters, industry publications, and articles, we evaluate problems that existed with SFAS 141 from the perspective of users, professionals, and the FASB; evaluate $141(R)$ to ascertain if these weaknesses were corrected; and propose solutions to some of the problems that still exist.
\end{abstract}

Keywords: Merger and acquisition accounting, global convergence, consolidation theory

\section{INTRODUCTION}

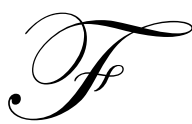

or many years, Accounting Principles Board (APB) Opinion No. 16, Business Combinations, guided the accounting process for business combinations. Opinion No. 16 was issued by the APB in 1970 and provided two methods of accounting for business combinations, the pooling of interests method (pooling) and the purchase method. Under the pooling method, a business combination was accomplished through an exchange of equity interests and accounted for on a book value basis. That is, the balance sheets of the two merging companies were simply added together, item by item. As a result, no other assets or liabilities were recognized and the difference between the value of stock exchanged and the book value acquired was recognized by using equity accounts (generally, retained earnings and contributed capital). Opinion No. 16 set forth 12 criteria that, if met, would allow the use of the pooling method. Otherwise, the purchase method was to be used. The purchase method accounted for acquisition on a fair-value basis with any premium paid over the fair value of the acquired company's assets being assigned to goodwill.

Business combinations were frequently structured using pooling to avoid the revaluation of assets and liabilities, to keep asset book values at historical cost, and to avoid the use of fair market values, all of which would increase future depreciation and other expenses and reduce net income. Also, some intangible assets were not recognized (i.e. goodwill, brand names, etc.). In August 1996 the Financial Accounting Standards Board (FASB) began to reconsider the accounting for business combinations when an increase in merger and acquisition activity brought greater attention to the inconsistencies in the accounting methods allowed. The objective was to improve the transparency of accounting for and the reporting of business combinations, including the accounting for goodwill and other intangible assets by reconsidering the requirements of Opinion No. 16 (FASB, 2001, p. 221).

The FASB Emerging Issues Task Force (EITF) began work on business combinations in 1997. The EITF found that because virtually all business combinations were acquisitions, requiring one method of accounting for economically similar transactions would be consistent with the concepts of representational faithfulness and comparability. Thus, one of the major reasons for revising Opinion No. 16 was that because the 12 pooling criteria did not distinguish between economically dissimilar transactions, similar business combinations were being accounted for using different methods that produced dramatically different financial statement amounts. As a result, users of financial statements were finding it difficult to compare the financial results of different entities. In addition, many people believed that the differences between the pooling and purchase methods were affecting competition in 
mergers and acquisitions markets. Entities that could not meet all of the criteria for using the pooling method believed that they faced uneven competition for possible acquisitions with entities that could apply that method (FASB, 2001).

Based on the EITF findings, the FASB decided that only the purchase method should be used to account for business combinations and that certain changes should be made in how the purchase method is applied. Thus, SFAS 141, Business Combinations, issued in 2001, overhauled accounting for business combinations by eliminating the pooling method and establishing the purchase method as the only method to be used in business combinations. FASB believed that with the issuance of Statement 141, financial reporting would be improved because the financial statements of entities that engaged in business combinations would better reflect the underlying economics of those transactions. Although the statement was based on a fundamentally different approach, the application of the purchase method of accounting remained essentially the same as it was under Opinion No. 16.

SFAS 141 was issued in June 2001 and was effective for all business combinations initiated after June 30, 2001. SFAS 142, Goodwill and Other Intangible Assets, was also issued in June 2001 and was effective for calendar year companies on January 31, 2002. SFAS 142 treated intangible assets as assets with indefinite useful lives and required that they no longer be amortized but tested at least annually for impairment. Intangible assets with finite useful lives would continue to be amortized. The effect of these two standards was to give combinations the impetus to allocate as much of the purchase price as possible to goodwill and as little as possible to identifiable assets.

In 2002, the FASB's EITF added business combinations again to its agenda. The task force addressed many ambiguities in SFAS 141 related to intangible assets and various implementation issues. The result was the issuance in December 2007 of SFAS 141(R), Business Combinations. The overarching theme of SFAS 141(R) was to make accounting for business combinations more in tune with the principle of fair value accounting, which the FASB and the International Accounting Standards Board (IASB) have embraced as the guiding principle for financial reporting in the march towards convergence of accounting theory and practice (Walsh, 2006, p. 2). SFAS 141(R) retains the elementary requirements of SFAS 141 but provides substantial accounting and implementation guidance in applying the purchase method, now called the acquisition method, when accounting for business combinations by establishing principles and requirements, including:

1. Recognition and measurement in financial statements of assets acquired, liabilities assumed, and equity interests, including non-controlling interests;

2. Recognition and measurement of goodwill acquired, including how goodwill is affected by the outcome of future events;

3. Recognition and measurement of a gain from a bargain purchase option; and

4. Revision of disclosure requirements.

\section{PURPOSE}

The objective of this paper is first to evaluate the accounting industry's response to SFAS 141 to determine if any problems were identified by financial statements users. Next, we'll compare SFAS 141 with SFAS 141(R) to determine what the FASB saw as problems with SFAS 141 and evaluate if the FASB was able to correct these problems. Finally, we will propose solutions to some of the problems that still exist.

\section{CRITICISMS OF SFAS 141}

When SFAS 141 was originally issued, users and professionals objected to some of the changes the FASB made including the elimination of the pooling method. While many complaints remained, by the time SFAS 141(R) was issued, most users and professionals had accepted the changes brought about by SFAS 141 (Graziano \& Heffes, 2008). Analysis of comment letters, industry publications and articles reveal that the complaints can be divided into two categories. 


\section{Minor Criticisms}

Minor criticisms pointed out that SFAS 141 did not include a definition of a business, did not define the acquirer, only applied to business combinations in which control was obtained by a transfer of consideration, and did not provide guidance on measuring the non-controlling interest's share of the consolidated subsidiary's assets and liabilities at the acquisition date. More emphasis was placed on issues such as the accounting for step acquisitions, contingent consideration, recognition of negative goodwill, in-process $\mathrm{R} \& \mathrm{D}$, and acquisition related costs.

\section{Major Criticisms}

The largest number of criticisms centered on the accounting for goodwill and intangible assets. The existence of goodwill meant that the acquirer paid more for an acquired entity than the value of the net assets. In accordance with SFAS 141, the excess of the cost of an acquired entity over the net values assigned to assets acquired and liabilities assumed was recognized as an asset referred to as goodwill. Accounting for goodwill was not changed from Opinion No. 16. Miller, Bahnson, \& McAllister (2008), state that this approach doesn't independently assess the existence or real value of goodwill, rather, it throws the residual into the goodwill account without regard to how much value actually exists. Thus, the assigned value is unlikely to reflect the full amount of enterprise goodwill.

The second largest concern was the accounting for intangible assets. SFAS 141 required that intangible assets be recognized apart from goodwill if they met either the contractual-legal criterion or the separability criterion (FASB, 2001, p.3). SFAS 141 set forth a lengthy list of intangible assets that must be assigned dollar values for each of the company's reporting units or business segments. The stringent rules governing the identification of intangibles caused controversy over what deserved separate recognition, especially if it was not expressly on this list. In addition, controversies existed over how asset values were assigned to relevant reporting units or business segments of a company. Moreover, disagreements existed on determining whether an intangible asset had an indefinite or a definite life, and if the latter, what that definite life was (Quick and Goldschmid, 2002). Finally, users disliked the difficulties of measuring the fair market values of identifiable intangible assets, which, in turn, made it difficult to accurately determine the amount recorded for goodwill (Lewis, Lippitt, \& Mastracchio (2001).

\section{FASB PRIORITIES IN ADDRESSING THE CRITICISMS}

The FASB's main objective in the issuance of SFAS 141(R) was to improve the relevance, representational faithfulness, and comparability of the information reported in financial statements about a business combination. SFAS 141 resulted in recognizing assets and liabilities at dates other than the acquisition date or at amounts other than their fair values at the acquisition date. The FASB recognized that the statement needed revision and wanted to address global harmonization and convergence issues. The analysis of FASB deliberation transcripts and other documents reveal that the following issues took priority:

1. Acquisition Related Costs: The FASB agrees with users that acquisition costs do not add value to acquired assets and therefore should not be included in goodwill.

2. Step Acquisitions: SFAS 141 results in recognizing and measuring assets and liabilities in a step acquisition at a blend of historical costs and fair values, a practice that results in providing information that is less relevant (Wendell, 2008).

3. Contingent Consideration: Under SFAS 141, contingent consideration obligations are not generally recognized at the acquisition date but rather, when the contingency is resolved and consideration is issued or becomes issuable. This means that contingent consideration provisions are ignored when determining the recorded cost of an acquired entity. Users point out that financial statements that disregard these potential cash flows are not sufficiently informative.

4. Recognition of Negative Goodwill: SFAS 141 stipulates that entities with negative goodwill should reduce the balance of long-term assets proportionally and transfer the remaining residual to extraordinary gains on the income statement. The FASB recognizes that these procedures cause the true values of those assets to be under-reported on the balance sheet. Users question whether the negative goodwill really constitutes a wealth-enhancing item or whether it relates to something else (Ketz, 2005). 
5. In-Process Research \&Development: Users complain and the FASB agrees that the treatment of in-process R\&D in SFAS 141 causes the consolidated balance sheet to omit relevant information about significant assets that help justify the acquisition. They believe that if part of the purchase price is attributed to the acquirer's valuation of in-process $R \& D$, then that value should be reflected in the financial statements as in-process R\&D and not expensed (Smith \& Saemann, 2007).

6. Non-controlling Interest: The FASB recognizes that SFAS 141 does not provide guidance on measuring the non-controlling interest's share of the consolidated subsidiary's assets and liabilities at the acquisition date. Thus, the replacement standard has to address the measurement of non-controlling interest at fair value to improve the completeness of financial statements and make them more comparable across entities.

7. Accounting for Contingencies: The FASB wants to correct the gaps in the way SFAS 141 measures the fair value of acquired assets and liabilities by recognizing and measuring assets and liabilities arising from contingencies. Also, the FASB recognizes that the inherent difficulty in measuring the fair value of contingent assets and liabilities is the availability and quality of information at the date of acquisition.

8. Bargain Purchase Gain: Current disclosures underreport balance sheet values and resulting estimates of earnings. The FASB hopes to correct the SFAS 141 procedures of handling negative goodwill and to improve the representational faithfulness and completeness of the information provided in consolidated financial statements by requiring the acquiring entity to report any excess of the fair value of the net assets acquired over the purchase price as a gain to the acquirer.

9. International Convergence of Accounting Standards: The FASB wants to deliberate the issue of business combinations in a joint effort with the IASB with the objective of developing global standards for the accounting for business combinations that are high-quality, can be used for both international and domestic financial reporting, improve financial reporting about business combinations, and promote the international convergence of accounting standards.

Overall, the FASB hopes that the broader scope of 141(R) will improve the comparability of the information about business combinations provided in financial reports.

\section{DID THE SFAS 141(R) SATISFY USERS AND MEET THE FASB's PRIORITIES?}

SFAS 141(R) emphasizes the reporting of assets and liabilities at their fair values rather than historical costs (FASB, 2007, pp. i-vi). Table 1 summarizes the major differences between SFAS 141 and SFAS 141(R). While the FASB addressed many criticisms of SFAS 141, users continue to have concerns about SFAS 141(R).

\section{Revised Definition of a Business}

SFAS 141(R) adopts a broader definition of a business and defines the acquirer as the entity that obtains control of the other business. This was a critical change because SFAS 141 only applied to business combinations in which consideration was transferred. As a result of this change, all business combinations must use the acquisition method, including those in which mutual entities combine with no consideration transferred. This will result in greater comparability of financial reports (FASB, 2007, p. ii). While some accountants feel that it is not practical to determine the fair value of an acquired company if there is no consideration transferred (Davis \& Largay, 2008, p. 27 ), this change is in line with FASB's goal of reporting assets and liabilities at their fair values.

\section{Expensing Acquisition Costs}

Acquisition costs incurred prior to the business combination were added to the purchase price of the transaction under SFAS 141. However, the FASB recognizes that these acquisition costs do not necessarily add value to the business acquired and therefore should not be recorded as an asset. Therefore, SFAS 141(R) requires that these acquisition costs be expensed as incurred. While this change more accurately reflects FASB's goal of fairvalue accounting, most respondents to the exposure draft pointed out that this approach is not consistent with transactions costs incurred outside of business combinations, such as the capitalization of installation costs when purchasing equipment. Opponents also pointed out that acquisition expenses are taken into consideration when determining a purchase price, therefore the expenses should be included as part of the investment costs rather than being expensed (Davis \& Largay, 2008, p. 30). 


\begin{tabular}{|c|c|c|}
\hline & Current GAAP & New Standard \\
\hline Definition of Business & Narrow & Broad \\
\hline Acquisition Expenses & Capitalized & Expensed \\
\hline In-Progress R\&D & Expensed & Capitalized \\
\hline Bargain Purchase Gain & $\begin{array}{l}\text { Negative goodwill: } \\
\text { Pro rata reduction } \\
\text { of particular assets }\end{array}$ & $\begin{array}{l}\text { Recorded as an ordinary } \\
\text { gain on the IS }\end{array}$ \\
\hline Goodwill Measurement & $\begin{array}{l}\text { Calculated as the excess } \\
\text { of investment cost over } \\
\text { acquirer's proportionate } \\
\text { share of net identifiable } \\
\text { assets }\end{array}$ & $\begin{array}{l}\text { Calculated as the excess } \\
\text { of the consideration } \\
\text { transferred plus the fair } \\
\text { value of any non-controlling } \\
\text { interest over the fair values } \\
\text { of net identifiable assets }\end{array}$ \\
\hline Contingent Considerations & $\begin{array}{l}\text { Recorded as part of the } \\
\text { cost of the combination } \\
\text { only if the contingency is } \\
\text { determinable at the date } \\
\text { of acquisition }\end{array}$ & $\begin{array}{l}\text { Recognized at acquisition- } \\
\text { date estimated fair value. The } \\
\text { acquirer estimates the fair } \\
\text { value of the contingent } \\
\text { portion of the total business } \\
\text { fair value }\end{array}$ \\
\hline Step Acquisitions & $\begin{array}{l}\text { Once control is achieved, } \\
\text { each investment layer's } \\
\text { book value is used to } \\
\text { determine the total } \\
\text { investment cost }\end{array}$ & $\begin{array}{l}\text { Once control is achieved, } \\
\text { each investment layer is } \\
\text { re-measured at acquisition } \\
\text { date fair value }\end{array}$ \\
\hline Disclosures & $\begin{array}{l}\text { Limited to describing } \\
\text { the acquisition's impact } \\
\text { on reported earnings } \\
\text { and the allocation of } \\
\text { the purchase price } \\
\text { between acquired assets } \\
\text { and liabilities }\end{array}$ & $\begin{array}{l}\text { Extensive list of disclosures } \\
\text { enabling the users of the } \\
\text { financial statements to } \\
\text { evaluate the nature and } \\
\text { financial effects of the } \\
\text { business combination }\end{array}$ \\
\hline Measurement Period & $\begin{array}{l}\text { The provisional amounts } \\
\text { must be adjusted for up } \\
\text { to one year after the } \\
\text { acquisition. No clear } \\
\text { guidance whether the } \\
\text { changes must be reported } \\
\text { as current income or } \\
\text { treated retroactively }\end{array}$ & $\begin{array}{l}\text { The measurement period } \\
\text { shall not exceed one year. } \\
\text { During that period the } \\
\text { acquirer shall restate } \\
\text { comparative statements } \\
\text { as if the revised amounts } \\
\text { had been known on the } \\
\text { date of the acquisition }\end{array}$ \\
\hline
\end{tabular}

\section{Accounting for Research and Development Costs}

SFAS 141(R) supersedes some of the procedures included in the Statement No. 142, Goodwill and Other Intangible Assets, which required research and development (R\&D) assets acquired to be immediately expensed subsequent to the acquisition (Miller, Bahnson, and McAllister, 2008, p. 36). The new Statement requires in-process R\&D costs to be measured at fair value, capitalized, and annually measured for impairment. While capitalizing inprocess $R \& D$ rather than grouping its implied value in goodwill gives readers of the financial statements more 
transparency, it is inconsistent with the treatment of $\mathrm{R} \& \mathrm{D}$ not obtained through an acquisition. Comment letters received by FASB disagreed with the new treatment and expressed opinions that R\&D projects should be accounted for in similar ways regardless of whether the costs are generated internally or through a business combination.

The Institute of Management Accountants wrote to FASB regarding this issue. The letter states that while the $R \& D$ activities and projects can be incurred, procured or acquired in various ways such as via internal $R \& D$ activities, through contracting activities, via licenses, as part of asset purchases, or via business combinations, at the conceptual level, these activities or projects should be accounted for in similar ways, regardless of how they are acquired (Desroches, June 2007, p. 3). Despite constituent objections, FASB believes this change increases the transparency of financial statements and is consistent with its goal of fair-value accounting.

\section{Bargain Purchase Gains}

SFAS $141(\mathrm{R})$ defines a bargain purchase as a business combination in which the total acquisition-date fair value of the identifiable net assets acquired exceeds the fair value of the consideration transferred plus any noncontrolling interest in the acquiree (FASB, 2007, p. iv). Rather than recognizing this value as negative goodwill, SFAS 141(R) requires that companies record a gain on the income statement. This change allows the assets acquired to remain at fair market value and improves transparency. SFAS 141 had required the excess of the assets acquired and liabilities assumed over the cost of the acquired entity to pro-ratably reduce the recorded value of certain assets. Any excess remaining was recognized as an extraordinary gain. This logic was criticized because assets were not recorded at their fair value and the reductions were arbitrary.

FASB succeeded in moving toward fair-value accounting with this change. However, constituents expressed concerns in comment letters over the change, stating that a gain could be recognized at the time of acquisition due to an acquirer potentially making intentional errors in measuring fair values of the 1) consideration paid for the business, 2) assets acquired, or 3) liabilities assumed or using measures that are in accordance with GAAP or IFRS that are not fair values (Silliman, 2008, p. 36). The treatment of goodwill and bargain purchases in SFAS 141(R) resulted in FASB member Leslie Seidman dissenting from the issuance of this Statement.

\section{Accounting for Goodwill and Non-Controlling Interest}

The amount of goodwill continues to be measured as a residual cost under SFAS 141(R). It is calculated as the excess of consideration transferred plus the fair value of any non-controlling interest in the acquired business at the acquisition date, less the fair values of the identifiable net assets acquired (FASB, 2007, p. iv). Acquisition costs, R\&D, and contingencies however will be separately valued reducing the goodwill residual. Some accounting professionals criticized the decision to use the entire fair value of the non-controlling interest in the acquired business when calculating goodwill. PricewaterhouseCoopers noted in its May 2007 comment letter to FASB \& IASB that, given the recent decision reached by IASB (2008) with respect to the full goodwill method, convergence will not be achieved. Indeed, under SFAS 141(R), the entire portion of non-controlling interest must be measured at fair value. Under the revised IFRS 3, non-controlling interest can be measured at its proportionate share of the identifiable net assets rather than at the full fair value (Graziano \& Heffes, 2008, p. 37).

Despite the differences between the new rules and international standards, most responses to the $141(\mathrm{R})$ draft agreed that recording identifiable assets and liabilities at their fair value was appropriate. However, goodwill is still a residual value that cannot be directly attributed to identifiable assets. Davis and Largay (2008) further explain the perceived inappropriateness of using the fair-value approach in measuring goodwill, as follows:

...the acquiree's total fair value cannot be measured when less than $100 \%$ is purchased and a "control premium" exists. Having control of another entity is a valuable right with numerous benefits, including the use of all the assets and the ability to declare dividends. Because the value of this right is reflected in the price necessary to obtain control, the premium theoretically no longer needs to be paid once control is obtained. Therefore, estimating the fair value of a whole entity based on the price paid to acquire control with less than 100\% ownership could significantly overstate the entity's true fair value (p. 27). 


\section{Contingencies and Contingent Considerations}

SFAS 141(R) requires that contractual contingent assets and liabilities be recognized at their fair value on the date of acquisition. Non-contractual contingencies must be recorded at their fair value if it is more likely than not than an asset or liability exists (VRC, 2008). Requiring accountants to recognize contingencies on the date of acquisition may increase transparency in the financial statements. However, contingencies are difficult to measure because they are based on the outcome of future events. FASB received many comment letters disapproving this complexity resulting from SFAS 141(R). In its Letter of Comment No 6 PricewaterhouseCoopers stated that the increased complexity will result from the difficulty associated with the initial and subsequent recognition and measurement of contingent assets and liabilities and from tracking of those assets and liabilities (PWC, 2007, p. 2).

In addition, a company often agrees to pay additional payments to the seller of a business based on the outcome of future business results. SFAS 141 didn't require companies to recognize these contingent consideration agreements until the event transpired. As a result, managers were not held accountable for what they negotiated and the financial statements did not adequately inform users of all potential liabilities surrounding the acquisition (Miller, Bagnson, and McAllister, 2008, p. 36). SFAS 141(R) requires companies to measure and record these contingent considerations at their estimated fair value at the time of sale. Time Warner controller, Pascal Desroches, has noted the counterintuitive result of this change by explaining that a company that does not meet their targets will record a gain by means of reducing the contingent consideration liability. As a result, he predicted that contingent consideration arrangements will be less prevalent after SFAS 141(R) goes into effect due to the potential financial statement volatility that can result from the agreements (Desroches, March 2007).

\section{Step Acquisitions}

SFAS 141(R) requires that each incremental investment be adjusted to fair value once control is achieved. Gains or losses resulting from these adjustments are reported in the income statement under current operations. This change is consistent with FASB's goal of stating assets and liabilities at their fair value. FASB concluded that a change from a non-controlling interest to a controlling interest of an entity is a significant change in the nature of and economic circumstances surrounding that investment that warrants a change in the classification and measurement of that investment (FASB, 2007, p. 384). Allowing acquirers to recognize a gain or loss when control is gained through step acquisitions differs from the prior purchase method used. However, FASB felt the recognition of the gain or loss is simply a delayed recognition that was not reflected in the financial statements due to the historical cost principle (FASB, 2007, p. 387).

Many respondents to the exposure draft of SFAS 141(R) felt that the gains or losses recorded as a result of adjusting the step acquisitions to fair value should be reported in other comprehensive income. This would be consistent with accounting from unrealized gains or losses on available-for-sale securities (Davis and Largay, 2008). FASB acknowledged this inconsistency and noted that changes in the value of available-for-sale securities are recognized in net income when the securities are derecognized. In a business combination achieved in stages, the acquirer derecognizes its investment asset in an entity in its consolidated financial statements when it achieves control (FASB, 2007, p. 389).

\section{Convergence with International Standards}

Although SFAS 141(R) was a joint project between the FASB and IASB, there continue to be differences in how the U.S. GAAP and international standards treat business combinations. Differences include guidance on how to value the non-controlling interest in an acquiree, contingent consideration, and assets and liabilities arising from contingencies. Most of the changes in prior procedures and rules implemented by the FASB in SFAS 141(R) are due to the desire to retain consistency with other FASB or IASB's standards. Both boards allowed differences to remain at this time since most issues will be addressed in current joint projects or are candidates for future joint projects (FASB, 2007, p. 333). 


\section{Disclosures and Re-measurements}

SFAS 141 disclosure requirements were limited to describing the acquisition's impact on reported earnings and the allocation of the purchase price between acquired assets and liabilities. SFAS 141(R) contains an extensive list of required disclosures enabling the users of the financial statements to evaluate the nature and effects of the business combination on projected financial outcomes.

In addition, SFAS 141 required that any provisional amounts originally recorded must be adjusted for up to one year but did provide guidance whether the adjustments should be reported as current operating income or be reported retroactively. SFAS $141(\mathrm{R})$ clearly states that the adjustment period shall not exceed one year with the acquirer restate the published comparative statements retroactively as if the revised amounts had been known on the date of the acquisition.

\section{PREDICTING FURTHER FASB/IASB ACTION}

\section{Improvements and Research in Accounting for Business Combinations}

Of the numerous comment letters the FASB received for its Exposure Draft on 141(R), many reflected the view that the changes would not increase transparency or improve the reliability and comparability of financial reporting. In fact, constituents argued that $141(\mathrm{R})$ would add to the complexity of financial reporting in certain areas thus making it more difficult for investors to understand the financial and operating performance of companies engaging in merger transactions (Chavern, 2005). In an unsolicited letter to the FASB Exposure Draft the Chair of the Financial Reporting Committee for the Institute of Management Accounting stated that the proposed accounting is not capable of being understood and consistently applied by preparers (Desroches, March 2007).

Stemming from the opinion that 141(R) would increase the complexity of accounting for business combinations, several respondents to the FASB Exposure Draft stated that some of the changes overlapped with current FASB projects on the Conceptual Framework. In the FASB's quest to move to fair value accounting, it is questionable as to whether accounting standards are still conforming to the accounting concepts of conservatism and comparability. The majority of the changes made by the FASB in effect produces more assets on the balance sheet or requires the recognition of gains and losses on the income statement. The fact that a business combination is now reflected at full fair value and includes non-financial assets and liabilities including contingencies would make it difficult to compare other entities still reporting historical cost. The financials will become more relevant and transparent but will not be as reliable, increasing the cost of reporting and auditing.

\section{Parent vs. Entity Concept \& Non-Controlling Interest}

The FASB's most controversial change to accounting for acquisitions is the move to the entity or economic-unit theory of consolidations instead of the currently used parent theory. The economic theory considers $100 \%$ of the entity because the parent is assumed to have control over the entire subsidiary. Under this theory, the entire entity is recorded at full value, including non-controlling interest, and the cost of acquisition based on ownership percentage is ignored. Non-controlling interest will now be included in stockholder's equity instead of as a liability or in a mezzanine section. This proposed change received a large number of criticisms as well as caused the dissent of one of the FASB board members.

Full convergence was not reached on this issue. While the FASB makes it mandatory to measure noncontrolling interests at fair value, the IASB offers the choice of using fair value or using the proportionate interest in the identifiable assets. KPMG IFRG Limited stated in its comment letter to FASB's exposure draft that it is inappropriate to gross up goodwill and non-controlling interests in business combinations in which less than 100\% of an acquiree is obtained (Teixeira, 2005). Since goodwill is defined as a residual in the combination, it should be attributed only to the parent and not the non-controlling interest when less than $100 \%$ is acquired because it could overstate the entity's true value. Additionally, non-controlling interest should not be included as part of stockholder's equity since it does not reflect the true equity of the company. 


\section{Contingencies \& Contingent Consideration}

The second most controversial issue was the change in contingency recognition. SFAS 5, Accounting for Contingencies, governed contingencies prior to the issuance of $141(\mathrm{R})$. It states that asset contingencies are never recorded and liability contingencies are recorded only when the contingency is probable and able to be estimated. Asset and liability contingencies relating to the acquisition of a business must now be recognized at fair value if it is more likely than not that an asset or liability exists at the time of acquisition. Contingent consideration occurs when part of the purchase price includes a future payment or refund based on performance. Prior to 141(R), these were not recorded in the financial statements. The new standard requires the contingency to be booked and continually marked to market until resolved.

The issue and main concern for many constituents is the valuation of the asset or liability. Contingencies by nature are conditional and uncertain. Markets are frequently not available to obtain fair values. Therefore, judgment is required to identify a reasonable value. Once a value is determined on the acquisition date, the contingency must be marked to market on a continuous basis. In addition to possibly providing unreliable information to users, it also creates an opportunity for management manipulation of financial information.

When referring to contingent consideration, Desroches states that the results often will be counterintuitive under the new rules (March 2007). A company could end up recording a gain (i.e., reducing a liability) to the extent that an acquired business does not perform as well as expected (Graziano \& Heffes, 2008, p. 37). While the reporting of contingencies is in line with the FASB's goal of fair value accounting, we believe that contingencies should remain as notes to the financial statements until they meet the probability and measurement requirements under SFAS 5, instead of being recorded based on an assessment of whether they are more likely than not to occur.

\section{In-Process R\&D}

While the reporting for In-Process R\&D (IPR\&D) acquired in a business combination under 141(R) increases transparency, it creates inconsistencies in the accounting methods for other IPR\&D. SFAS 2, Accounting for Research \& Development Costs, requires all IPR\&D, except that which is acquired through a business combination, to be expensed. SFAS 141(R) states that acquired IPR\&D should be listed at its fair value in the consolidated financial statements as an intangible asset and be tested occasionally for impairment. Future investments in R\&D following the acquisition date will continue to fall under SFAS 2 and SFAS 142. The question is why does acquired IPR\&D have value, while future additions to the acquired IPR\&D or internally developed IPR\&D do not? The method for reporting IPR\&D should be the same regardless of the manner it is acquired.

The FASB and IASB agreed on how to handle IPR\&D acquired from a business acquisition. However, differences remain for non-acquired R\&D. Currently, IAS 38, Intangible Assets, provides the accounting guidance for R\&D expenditures. Expenditures relating to the research portion of a project are never recognized as an intangible asset and are expensed as incurred. Development expenditures may be recognized as assets if they meet the IASB's definition of an intangible asset and meet six criteria. Given the opportunity to capitalize IPR\&D, one would expect mergers with IPR\&D to increase.

\section{CONCLUSIONS}

While the FASB believes it has succeeded in improving the relevance and representational faithfulness of financial reporting for business combinations with the issuance of $141(\mathrm{R})$, it is clear that constituents believe that there is still work to be done. Although complete agreement between constituents and the FASB is unlikely, the efforts made to harmonize U.S. GAAP with international standards and the FASB's efforts to improve financial reporting for business combinations are encouraging.

\section{RECOMMENDATIONS FOR FUTURE RESEARCH}

Respondents to the FASB thought users would be better served if the Board addressed only true convergence issues in $141(\mathrm{R})$ and allowed other fundamental issues to be resolved in the Conceptual Framework 
project. Thus, issues such as the parent company view of the reporting entity versus the economic unit view, the recognition and measurement principles for contingencies, and the handling of $R \& D$ activities are ripe for further research to determine which approach produces results relevant to financial decisions. In addition, future research can determine the level of additional costs incurred by firms in meeting the 141(R) requirements. Also, it will be interesting to follow IASB and FASB deliberations to see how the differences in the valuation of non-controlling interests will be reconciled. Next, research examining the outcome of asset and liability contingency accruals will provide useful information. Finally, research examining the trends in mergers with IPR\&D issues would provide key information for standard setters.

\section{AUTHOR INFORMATION}

Christine P. Andrews is an Associate Professor of Accounting at Florida Gulf Coast University. She has worked as a CPA in public accounting, a cost analyst in manufacturing, and as an analyst in banking. She holds a D.B.A. in Accounting from Cleveland State University. Her current research interests include pedagogical issues including service learning and distance education and issues related to information systems security, environmental accountability. Her research has appeared in The CPA Journal, Journal of Accountancy, the Journal of Business Education, Commercial Law Journal and Business Horizons

Jan Brown is a graduate student at FGCU pursuing her M.S. in Accounting and Taxation and CPA license. She graduated summa cum laude from Missouri State University in 2004 with a business degree. Jan is a Senior Accountant at Gartner where she is responsible for managing international accrued liability accounts and worldwide Events accounting. She also works as a graduate assistant teaching a course at FGCU. She is a member of Beta Gamma Sigma and volunteers at Lee Memorial Hospital and Grace Church.

Jeannette Riley was born and raised in Michigan. She received her BS in Finance from Oakland University. After working as an insurance claims adjuster for a number of years, she left to pursue a career in construction. She was a licensed residential builder with her own company before the economic downturn brought her to Florida. She currently works as church administrator at Crossroads Baptist Church overseeing the operations of the church including all of the financial and accounting work. She is enrolled as a graduate student at FGCU and hopes to sit for the CPA exam in 2010.

Originally from Michigan, Carrie Todd moved to SW Florida in 1993. She graduated magna cum laude from FGCU in 1999 with a degree in Finance. Between 1995 and 2007 she co-owned multiple small businesses in SW Florida, Michigan and California. In order to gain more knowledge and experience in larger organizations, she joined Gartner in April 2007 as a Senior Accountant. She is currently enrolled in FGCU's Accounting and Taxation Masters Program and is working towards the CPA designation in order to pursue career goals. She is a member of FGCU's Beta Alpha Psi/Accounting Club, Golden Key Organization and Toastmasters.

Ara G. Volkan, Ph.D., CPA, is the Chair of the Accounting and Finance Department at Florida Gulf Coast University. He joined the FGCU faculty in August 2004 as Eminent Scholar and Moorings Park Chair of Managerial Accounting. He received his doctorate in accounting from the University of Alabama in 1979. He holds a CPA certificate in Florida (1989). Following his teaching engagements at Syracuse University (1979-1985) and at University of South Alabama (1986-1989), Dr. Volkan chaired the Accounting and Finance Department at University of West Georgia (1989-2003) and was Interim Dean at the Richards College of Business at West Georgia (2003-2004). He is a member of the board of directors Moorings Park, Inc. and its Finance Committee, the chair of the MPI Audit Committee, and the treasurer of Moorings Park Community Health, Inc. in Naples, FL. Dr. Volkan is a member of the AICPA, FICPA, IMA, and AAA. He has authored numerous articles in academic and professional accounting journals and in other business outlets.

\section{REFERENCES}

1. Chavern, D. (October 2005). US Chamber of Commerce Letter of Comment No. 17 to FASB Exposure Draft Reference Number 1204-001. FASB, Norwalk, CT. Retrieved from www.fasb.org 
2. Davis, M., and Largay, J. (February 2008). Consolidated Financial Statements, The CPA Journal, 78(2), 26-31.

3. Desroches, P. (June 2007). Institute of Management Accountants Letter of Comment No 2A to FASB Exposure Draft Reference Number 1204-001. FASB, Norwalk, CT. Retrieved from www.fasb.org

4. Desroches, P. (March 2007). Institute of Management Accountants Letter of Comment No 2 to FASB Exposure Draft Reference Number 1204-001. FASB, Norwalk, CT. Retrieved from www.fasb.org

5. $\quad$ FASB. (Dec 2007). Statement of Financial Accounting Standards No 141: Revised-Business Combinations. FASB, Norwalk, CT.

6. FASB. (2001). Statement of Financial Accounting Standards No 141: Business Combinations. FASB, Norwalk, CT.

7. Graziano, C, and Heffes, E. (April 2008). A Step towards Convergence in M\&A Accounting, Financial Executive, 24(3), 34-41.

8. International Accounting Standards Board. (January 2008). Business Combinations Phase II: Project Summary and Feedback Statement. IASB, London.

9. Ketz, J.E. (January/February 2005). Negative Goodwill: An M\&A “Fix” That Doesn't Work, The Journal of Corporate Accounting \& Finance, 16(2), 47-50.

10. Lewis, E, Lippitt, J, and Mastracchio, N. (October 2001). Users' Comments on SFAS141 and 142 on Business Combinations and Goodwill, The CPA Journal, 71(10), 26-30.

11. Miller, P, Bahnson, P, and McAllister, B. (June 2008). A New Day for Business Combinations, Journal of Accountancy, 205(6), 34-39, 12.

12. PriceWaterhouseCoopers (2007). Letter of Comment No. 6. to FASB Exposure Draft Reference Number 1204-001. FASB, Norwalk, CT. Retrieved from www.fasb.org

13. Quick, P., and Goldschmid, M. (Jan 2002). FASB Statements 141/142 and the Business Economist Where, Oh Where, Have My Intangibles Gone? Business Economics, 37(1), pp. 61-63.

14. Silliman, B. (March-April 2008). FASB Revises Rules for Business Combinations: Adoption of Acquisition Method Improves Fair-Value Reporting, Commercial Lending Review, 24(2), 32-36.

15. Smith, P, and Saemann, G. (April 2007). Implications of the Joint FASB and IASB Proposal on Accounting for Business Combinations, The CPA Journal, 77(4), 16-21.

16. Teixeira, A. (Oct 2005). KPMG IFRG Ltd Letter of Comment No 88 to FASB Exposure Draft Reference Number 1204-001. FASB, Norwalk, CT. Retrieved from www.fasb.org

17. Valuation Research Corporation. (2008). FASB Issues Business Combinations Statement. Retrieved from www.valuationresearch.com/content/Knowledge_center/back_issues/64_2008_1.htm.

18. Walsh, J. (December 2006). Business Combination Accounting and SFAS 141R, Valuation ViewpointsAnnual Newsletter of Navigant Capital Advisors, Issue 3, 2-3.

19. Wendell, P. (February 2008). Revised Business Combinations Accounting. SEC Accounting Report, 34(3), $1,3-5$. 
NOTES 